\title{
REWARD SYSTEM OF SINGLE SALARY AND PERFORMANCE IN THE HIGHER EDUCATION
}

\author{
Aniek Hindrayani, Universitas Sebelas Maret \\ aniek_h@staff.uns.ac.id \\ Muhtar, Universitas Sebelas Maret \\ abujebi@gmail.com
}

\begin{abstract}
This study aimed to evaluate the performance of employees after the implementation of the remuneration policy to the Higher Education and identify the reward policy and performance patterns with the pattern payroll employee remuneration and employee satisfaction levels. This study uses secondary data from the financial statements and the primary data in the form of interviews using questionnaire with the selected respondents in the sample, the academic staffs who have earned a salary based on the pattern of a single salary. The results showed that the financial performance in the achievement of $90.11 \%$ of payroll pattern showed a good indicator, but there are $0.89 \%$ of the budget that is not absorbed, which means the percentage of the expected performance can not be achieved. Analysis of the performance behavior indicate that there are changes in the behavior of post-implementation performance of the employee remuneration. Variance test results indicate that there are significant differences in the pattern of implementation of the remuneration in universities in Indonesia, which is indicated by the indicator system and the implementation of remuneration policies.
\end{abstract}

Keywords: Remunerations, Single Salary, Higher Education, Performance, Job Satisfaction.

\begin{abstract}
ABSTRAK
Penelitian ini bertujuan untuk mengevaluasi kinerja karyawan setelah pelaksanaan kebijakan remunerasi ke Perguruan Tinggi dan mengidentifikasi kebijakan reward dan pola kinerja serta pola penggajian dan tingkat kepuasan karyawan. Penelitian ini menggunakan data sekunder dari laporan keuangan dan data primer dalam bentuk wawancara menggunakan kuesioner dengan responden yang dipilih dalam sampel, yaitu staf akademik yang telah mendapatkan gaji berdasarkan pola gaji tunggal. Hasil penelitian menunjukkan bahwa kinerja keuangan dalam pencapaian 90,11\% dari pola penggajian menunjukkan indikator yang baik, tetapi ada 0,89\% dari anggaran yang tidak terserap, yang berarti persentase kinerja yang diharapkan tidak dapat tercapai. Analisis perilaku kinerja menunjukkan bahwa ada perubahan perilaku kinerja karyawan pasca pelaksanaan remunerasi. Hasil pengujian menunjukkan bahwa terdapat perbedaan yang signifikan dalam pola pelaksanaan
\end{abstract}


remunerasi pada perguruan tinggi di Indonesia, yang ditunjukkan oleh indikator sistem dan implementasi kebijakan remunerasi.

Kata Kunci: Remunerasi, Gaji Tunggal, Kuliah, Pendidikan Tinggi, Kinerja, Kepuasan Kerja.

\section{BACKGROUND}

Universities in Indonesia are expected to have an independent financial management pattern in 2014 with the option of applying the Financial Management of Public Service Agency or Higher Education Legal Entity. As a consequence of the election of the Financial Administration of the Public Service, the University should implement a payroll from one source with a form of remuneration. On the Regulation of the Minister of State for Administrative Reform No. PER/15/MPAN/7/2008 on General Guidelines for Reforms, said that remuneration dedicated to all government employees in all Government Institutions. Based on the urgency, the remuneration policy are grouped into three priorities, namely:

1. The first priority is a whole cluster of Law Enforcement Agencies, State Finance Cluster business, Group Inspectors, and the State Comptroller and the Institute of Administrative Publishing;

2. The second priority, is the Ministry/Agency related to economic activity, production systems, income sources of state revenue, and organizational units that serve people directly, including the Local Government;

3. The third priority, is the whole ministry/agency, not including the first and second priority.

Higher Education of Public Service Agency is expected to implement a remuneration no later than 2014. If they did not apply the remuneration pattern, then the work unit will be faced with the alternative of financial management with a way back to regular unit management scheme or switch to a management pattern of Higher Education Legal Entity, which is more complicated standards.

Determination of the remuneration pattern in Universities applying the principle of budgetary efficiency, and performance-based incentives through the one source of budget. The application of the remuneration pattern reflects the efforts of Higher Education to prioritize public services in the bureaucratic reform in order to create a reliable employee, professional, and clean, based on good governance and clean government. The rules according to the first, Key Performance Indicator (KPI) of the Universities, the Qualified Good Governance University Governance, and second, the realization of autonomy and independence of the university. Remuneration patterns expected to the impact on better employee performance behavior changes. Implementation of the remuneration in Higher Education is not easy to do. Changes in mindset and behavior patterns require understanding and awareness of the entire academic community to the understanding of such heterogeneous remuneration. Building awareness is the first step required in the implementation of the remuneration, that the working unit with Financial 
Management based on Public Service Policy, only have a choice of financial management by: (1) run a pattern of remuneration, (2) back to working unit usual, or (3) changing the pattern becomes Universities Incorporated. Each pattern of financial management has consequences, which are not easy to implement.

The existence and condition of Higher Education that allows to implement a remuneration in 2014, financing the payroll is done through one source of budget (single salary), to include all elements of the source of funds, the source of funds from State Budget and Operational State University Donate and Non Tax Revenue. The allocation of the budget used to pay the basic salary, functional allowance and professional allowance that are centralized. While the allocation of non-tax revenues amounting to a maximum of $40 \%$ is used to pay performance incentives with the proportion of $30 \%$ of performance based on the position in the Grade particular, and $70 \%$ of performance based on achievement beyond the performance of the principal, up to the performance of $150 \%$ for employees of non-educational, and performance up to $200 \%$ for employees of education, that are managed independently by the University. This opportunity expected to spur employees to achieve maximum performance achievement, in order to encourage the achievement of the University's performance scaled in the form of KPI Rector. KPI Rector is a performance contract with the Ministry of Finance, which the achievable to be one of the guidelines for remuneration to employees, with the participation of all elements in the university environment.

Consequently all employees must change mindsets and behavior patterns to work-based achievements. On the implementation side, it is possible the existence of patterns of thought and behavior that does not support the consequences of this remuneration. Changes in mindset linked to performance targets to be achieved, should be in accordance with the performance targets in the realm of KPI and the perspective of the remuneration pattern is the achievement of the above performance standards. Changes in behavior, associated with behavioral support achievement of the agreed KPI, behavioral changes in the management behavior of remuneration system, and after getting the performance incentives that impact on changes in work patterns and changes in consumption patterns. The application of the remuneration in the first year needs to be assessed to obtain a model of proper implementation and proper management in accordance with the regulations that have been issued.

Consideration of the budget allocation to meet the needs of remuneration is the salary expenditure and spending on goods and other services in the Entry List Implementation Budget 2014 derived from other services expenditures (Code 525 111) and shopping goods (Code 525 119) when put together. Meanwhile, when the remuneration allocated in the budget to meet the applicable provisions, which amounted to $40 \%$ of non-tax revenues are received, but in reality the budget is absorbed less than $40 \%$, so there is a budget surplus is not absorbed by the employees. Which means there is employee performance is not achieved when viewed from the amount budgeted funds. Implementation of the remuneration to be targeted, providing appropriate reward employee performance. 
Research on the evaluation of the implementation of the remuneration of the Universities in Indonesia is done partially by Agrimahera and Adam (2014), with a single source of assessing the implementation of the remuneration is less able to measure the performance of lecturers. In the study mentioned that the remuneration is applied to the University " $\mathrm{X}$ " in accordance with the principles of fairness, decency, and eligibility according to Government Regulation No. 23 of 2005 and PMK No. 10 of 2006, but less transparent and single salary. The principle of transparency and the single salary has not been carried out in accordance with legislation. Research by Trisnawati and Adam (2015), showed that the remuneration implemented on civil servants and non-civil servant lecturer has met the criteria of a fair, decent, reasonable, proportionality, equality and decency in accordance with the mandate of the PP 23 of 2005 and PMK 10, 2006.

Both the results of these studies refer to the proposed qualitative remuneration that have been published in the form of Financial Ministry Regulation, so the author's knowledge, this study is the first to publish the theme of evaluation of the implementation of remuneration on Higher Education in Indonesia. In this study evaluated the implementation of the remuneration of faculty and nonfaculty, in this case the researchers refer to as educators and education personnel in accordance with the legislation in force. The study was conducted after the implementation of the remuneration to identify the performance of the budget and employee satisfaction surveys.

Lee (2009) examined the performance-based remuneration to the CEO in the company's Australia and Singapore experiencing improved financial performance, but has a different board structure. The results showed that the payment of performance related to changes in performance, but the proportion of payment is not related to board structure. Large companies in both countries using performance-based remuneration which is paid based on the sales revenue.

Mc Gregor (2015) examined the implementation of the remuneration of the senior and junior academics at universities in South Africa, found that senior academics get paid better than junior academics. Senior lecturer to full professor, which means that the best researchers receive remuneration higher than junior faculty. However, junior faculty get better remuneration of the staff, it is mainly gives an opportunity to the master's and doctoral degrees to do more research.

Nazir, et.al. (2013) examined the relationship job satisfaction and remuneration in Pakistan viewed from the perspective of higher education institutions, shows that lecturers at the University have been given training on the knowledge, but not yet known work satisfaction. When further investigation, discovered the relationship between job satisfaction and remuneration. Payment is the deciding factor in job satisfaction Higher Education. Therefore, the need to increase job satisfaction and remuneration of lecturers through fostering a culture of learning.

Remuneration Payroll Implementation Patterns in Higher Education in Indonesia stated in 2014. Research on the implementation of remuneration on Higher Education in Indonesia has not been found. Implementation of remuneration in the College use the single salary system, where the entire 
payment of fees and the salary comes from one source, namely Entry List Implementation Budget of Public Service Agency. Entry List Implementation Budget in the details, the source of the budget comes from the state budget, Operational State University Donate, and non-tax revenues. Budget allocation and Operational State University Donate used to pay Salary, Position Allowance, Functional Allowance, Professional Allowance, and the Meal Allowance and budget non-tax revenues are used to pay for additional performance other than those paid by state funds and Operational State University Donate. The amount of budget non-tax revenues are used to pay salaries, to a maximum of $40 \%$ of the total non-tax revenues. The funds are paid to assess the performance of employees, through the payment of pay for position (by $30 \%$ of the maximum $100 \%$ allocation to each Grade) and pay for performance (by $70 \%$ of the maximum $200 \%$ allocation to each Grade on lecturers, and $150 \%$ for academic staff).

This study analyzes the forecast funding needs to meet the payment of remuneration in Higher Education, with a maximum of $40 \%$ of non-tax revenues. The lower the percentage of non-tax revenues are used to pay the above performance standards, then in terms of the proportion of the funding, the better, meaning that a large percentage of the other is used to meet the needs of academic services. Next in terms of employees, studied the behavior associated with academic performance and behavior after the consumption of the implementation of the remuneration. The higher the performance of employees, the higher the reward the performance obtained in the form of pay for performance. The higher the reward obtained, then the income of employees is increasing, in the pattern of economic behavior, the higher the income, the higher the person's level of consumption. If the line is drawn from the performance rewards system is given in the form of remuneration, this study wants to examine more deeply, whether the pattern of remuneration applied to improve the performance and welfare of employees, when seen from the performance indicators of behavior and consumption behavior.

This study also evaluates the implementation of appropriate remuneration ideal financial capacity of universities, based on the elements of financial receipts which have been calculated accurately and accountably. Evaluation also assessed the implementation of the level of employee satisfaction in obtaining reward performance, with proxy changing patterns of individual performance.

Using secondary data such as financial statements and primary data in the form of interviews and using questionnaire to evaluate the performance of employees after the implementation of the remuneration, this study identify the implementation of the system and the remuneration policy and individual performance patterns with the pattern payroll employee remuneration and employee satisfaction levels; and identify patterns of remuneration that have been implemented in universities in Indonesia. In particular, this study aims to examine (1) there is a post-implementation budget efficiency remuneration; (2) an increase in employee performance with a performance-based remuneration patterns through remuneration; (3) an increase in employee satisfaction after the implementation of the remuneration; and (4) there are differences in implementation patterns of remuneration in Universities. 
Salary payment patterns based remuneration consequences performing behavioral changes among employees, the higher the performance, the higher the performance incentives received. Individuals will pay more attention to performance indicators with components that assessed the performance remuneration. Multiplier effects arising from incentives received are the changes in consumption patterns of employees. Research problems that arise are (1) why are there differences in the realization of the payment of remuneration to the budget planned ?; (2) indicators of what causes the difference in the implementation of the remuneration to the proposed remuneration in the amount of budget and realization ?; (3) is there an increase in employee performance before and after implementation of remuneration?; 4 ) is there a change in the level of employee satisfaction after the implementation of remuneration ?; and (5) are there differences in the implementation of the system and remuneration policy among universities in Indonesia.

The results showed that the financial performance in the achievement of $90.11 \%$ of payroll pattern showed a good indicator, but there are $0.89 \%$ of the budget that is not absorbed, which means the percentage of the expected performance can't be achieved. Analysis of the performance behavior indicate that there are changes in the behavior of post-implementation performance of the employee remuneration. Likewise, consumption patterns, the results showed that there is a change in consumption patterns after the implementation of the remuneration of employees. Variance test results indicate that there are significant differences in the pattern of implementation of the remuneration in universities in Indonesia, which is indicated by the indicator system and the implementation of remuneration policies. Furthermore, the organizing of this article includes research methods, results and discussion, and conclusions.

\section{RESEARCH METHOD}

The sample of this research are the Universities in Indonesia, to examine the implementation model, achievement of budget allocation, system and remuneration policy, the behavior of individual performance and employee satisfaction. To test the suitability of the implementation of the remuneration in the college with plans that had been developed, used samples of three Universities based University jointly implement the remuneration system.

The object of this study is planning budgeting and financial performance reports on colleges to identify the prediction of a more appropriate allocation of funds to meet the needs of remuneration. The next object is to get reward employees for performance through a system of payroll salary remuneration with a single model to identify the behavior of the performance and behavior to consume as indicator in improving the welfare of employees at Universities. In order to achieve the common goal of the first study, samples were taken by simple random sampling. Open and closed questionnaire given to respondents selected as samples. The number of respondents planned on the entire sample of 300 from universities are expected to have been representative of the population as a sample. 
This study uses primary data and secondary data. Primary data obtained by asking questions to respondents through questionnaires open and closed, and open interviews. Secondary data were obtained from documents related to financial governance.

This research is quantitative descriptive. The general objective of this study was (1) to evaluate the performance of employees after the implementation of the remuneration to identify changes in the pattern of employee performance with the pattern of payroll remuneration and employee satisfaction levels; and (2) identify patterns of remuneration that have been implemented in universities in Indonesia. To achieve these objectives gradually testing. In the first general purpose, evaluation of the implementation of the remuneration carried by reviewing financial statements and the remuneration budget realization. The data were analyzed using simple percentages to prove the achievement of the budget. The next is to evaluate the performance of employees, by identifying behavioral performance and changes in employee satisfaction, as an indicator that the remuneration system can improve employee performance. To determine this behavior, structured questionnaire with a 5-point Likert scale, to obtain primary data were tested using simple regression. Open interviews are also conducted to support the fulfillment of the needs of the primary data collected through questionnaires. The analysis was performed by descriptive narrative.

In the second general purpose, the data obtained through questionnaires, arranged on the points system and criteria for the implementation of the remuneration policy at the college in general, with a 5-point Likert scale. Testing was performed using One Way Anova to prove that there are differences in implementation patterns of the remuneration system and policy at universities in Indonesia.

\section{RESULTS AND DISCUSSION}

This study uses primary data to determine the implementation of the remuneration in the Universities. Retrieving data using questionnaires distributed to respondents in the sample locations were selected to represent the population in this study. Sampling was done randomly, the respondent is an employee at the Higher Education and an allowance remuneration. Samples do not differentiate grade in remuneration and employment status. The total sample of 209 respondents, 300 questionnaires were distributed at three universities, or respond rate of $70 \%$. The number of respondents who can't be a source of data caused by system administration and policy target sample one of the universities do not give permission to do this research.

Of the distribution, descriptive statistical tests performed using SPSS 21. Descriptive statistical test result data can be seen in the table 1 .

Based on the table 2, it can be said that the number $\mathrm{N}$ is valid for 60 to variable Systems and Policies had a mean 6.2739, variable performance at 5.1148 , and variable job satisfaction at 6.1000 .

The validity test results show that the data obtained meet the criteria of valid and reliable with a significance level of $10 \%$. The test results can be seen in the table 2. 
Table 1. Descriptive Statistics Mean

\begin{tabular}{|c|c|c|c|c|c|c|c|c|}
\hline & $\begin{array}{c}\mathbf{N} \\
\text { Statistic }\end{array}$ & $\begin{array}{c}\text { Range } \\
\text { Statistic }\end{array}$ & $\underset{\text { Statistic }}{\text { Minimum }}$ & $\underset{\text { Statistic }}{\text { Maximum }}$ & $\begin{array}{r}M \\
\text { Statistic }\end{array}$ & $\begin{array}{l}\text { an } \\
\text { Std.Err }\end{array}$ & $\begin{array}{c}\text { Std. } \\
\text { Dev. } \\
\text { Statistic }\end{array}$ & $\begin{array}{l}\text { Variance } \\
\text { Statistic }\end{array}$ \\
\hline $\mathrm{Q}$ & 60 & 2.09 & 4.91 & 7.00 & 6.2739 & .07999 & .61956 & .384 \\
\hline K & 192 & 4.90 & 2.10 & 7.00 & 5.1148 & .05162 & .71528 & .512 \\
\hline $\mathrm{P}$ & 60 & 2.20 & 4.80 & 7.00 & 6.1000 & .07611 & .58956 & .348 \\
\hline $\begin{array}{l}\text { Valid N } \\
\text { (listwise) }\end{array}$ & 60 & & & & & & & \\
\hline
\end{tabular}

Table 2. Validity Testing Results

\begin{tabular}{lccc}
\hline \multicolumn{1}{c}{ Variable } & $\begin{array}{c}\text { Number of Items } \\
\text { Tested }\end{array}$ & Not Valid & Valid \\
\hline Systems and policies & 68 & 19 & 49 \\
Individual Performance & 20 & 0 & 20 \\
Job Satisfaction & 25 & 2 & 23 \\
\hline \multicolumn{1}{c}{ N } & 113 & 21 & 92 \\
\hline
\end{tabular}

Based on the Table 2 above, it can be said that of 113 items of remuneration implementation evaluation indicator testing is done, 92 items declared valid, or by $81.42 \%$. Next done reliability testing, the test results are presented in the following table.

Table 3. Results of Testing Reliability

\begin{tabular}{|c|c|}
\hline Cronbach's Alpha & N of Items \\
\hline 0.921 & 113 \\
\hline
\end{tabular}

The reliability of data for 0921 , so that it can be concluded that the test results demonstrate the validity and reliability of the results are valid and reliable, so it can be tested statistically.

Analysis of the performance behavior indicate that there are changes in the behavior of post-implementation performance of the employee remuneration. Likewise, consumption patterns, the results showed that there is a change in consumption patterns after the implementation of the remuneration of employees.

In the second general purpose test is done using a $t$ test to prove that there are differences in implementation patterns of remuneration at universities in Indonesia, with the indicator variables and testing the system of remuneration policy. The test results are in the following table.

Table 5. Results of t test

\begin{tabular}{|c|c|c|c|c|c|}
\hline \multirow[t]{2}{*}{ Model } & \multicolumn{2}{|c|}{$\begin{array}{l}\text { Unstandardized } \\
\text { Coefficients }\end{array}$} & \multirow{2}{*}{$\begin{array}{c}\text { Standardized } \\
\text { Coefficients } \\
\text { Beta }\end{array}$} & \multirow[t]{2}{*}{$\mathbf{t}$} & \multirow[t]{2}{*}{ Sig. } \\
\hline & B & Std. Error & & & \\
\hline \multirow{2}{*}{1 (Constant) Q } & 0.174 & 0.095 & & 1.825 & 0.073 \\
\hline & 0.945 & 0.015 & 0.993 & 62.583 & 0.000 \\
\hline
\end{tabular}

Based on the table above, it can be said that the coefficient $t$ in 0.945 showed significant $1 \%$, so it can be concluded that proved there were 
significant differences in the pattern of implementation of the remuneration of universities in Indonesia, which is indicated by the indicator system and the implementation of remuneration policies.

\section{CONCLUSIONS}

The test results on the first aimed showed that there is a change in the pattern of employee performance and employee satisfaction after the implementation of the remuneration. Statistical test results indicates that there are differences in the implementation of the remuneration in college, with a significance level of $1 \%$. The result is expected to benefit the Higher Education institutions, employees and academics in the behavior pattern of financial management in this particular payroll system of the door with the pattern of remuneration. The benefits of this research can be described as follows:

1. Provide recommendations on procedures for financial management in the payroll system of the single budget through a pattern of remuneration, which affects the amount of non-tax revenues allocated budget on remuneration expenditures.

2. Provide inputs for the leaders on the implementation of remuneration on performance over the standard indicators can be assessed by the remuneration

3. Provide recommendations for policymakers on behavioral assessments were given a reward employee performance with remuneration pattern.

4. Enrich the theory of the payroll system (reward and punishment) to improve the performance of human resources and improvement of governance towards good university governance.

\section{REFERENCES}

Agrimahera, VA and Adam, Helmy. 2014. Remuneration System Evaluation Lecturer of Public Service Agency for Higher Education (Case Study in University "X"). Accessed from http://download.portalgaruda.org/ article.php\%3Farticle\%3D189190\%26val\%3D6467\%26title\%3DEVAL UASI\%2520SISTEM\%2520REMUNERASI\%2520DOSEN\%2520BAD AN\%2520LAYANAN\%2520UMUM\%2520\%2520PERGURUAN\%252 0TINGGI\%2520\%2520, pada tanggal 07 April 2015, pukul 03:13.

Al Hinai, Iises Ziyana dam Bajracharya, Arun. 2014. A Study on The Factors Affecting Job Satisfaction of Academic Staff in Higher Education Institution. 13th International Academic Conference, Antibes. ISBN 978-80-87927-05-2. Accessed on April, $07 \quad 2015$ file://D:/Downloads/proceeding-8-4-160.pdf

Decree of the Minister of Finance of the Republic of Indonesia 387 / KMK.05 / 2014 on the Determination of Remuneration for official business, the Board of Supervisors, and Employees of the Public Service Agency of Universitas Sebelas Maret Surakarta of the Ministry of Education and Culture, dated August 19, 2014 
Lee, Janet. 2009. Executive performance-based remuneration, performance change and board structures. The International Journal of Accounting. Vol. 44, pp. 138-162.

MacGregor, Karen. 2015. Top Academics Well Paid, New Generation Falling Behind. University World News Global Edition. Issue 351. Accesed on April 07, 2015, from http://www.universityworldnews.com/article.php? $\underline{\text { story }=20150123082926550}$

Nazir, Tahira, Syed Fida Hussain Shah, and Khalid Zaman. 2013. The Relationship between Job Satisfaction and Remuneration in Pakistan: Higher Education Institutes Perspectives. Academia Arena. Vol. 5(2). Diakses pada tanggal 08 April 2015, pukul 10:35 dari http://www.sciencepub.net/academia.

Trisnawati, Novi and Adam, Helmy. 2014. Remuneration Syatem for Lecturer for Public Service Agency in Higher Education. Accesed on April, 07, 2015, from jimfeb.ub.ac.id/index.php/jimfeb/article/download/1562/ 1430. 